\title{
Government policies and firm performance in the COVID-19 pandemic era: a sectoral analysis
}

\author{
Danny Turkson $^{1}$ (D) Nana Boakyewaa Addai ${ }^{2} \cdot$ Farhat Chowdhury $^{2}$. \\ Fatima Mohammed ${ }^{3}$
}

Received: 30 January 2021 / Accepted: 27 October 2021 / Published online: 22 November 2021

(c) The Author(s), under exclusive licence to Springer Nature Switzerland AG 2021

\begin{abstract}
The effect of the COVID-19 pandemic has been severely detrimental to most firms. Preliminary estimates from Italy, which experienced the worst devastation from the virus during the early days of the pandemic, predicted that the country could lose at least $\$ 8.3 \mathrm{bn}$ in the service and manufacturing sectors due to the coronavirus pandemic. Although there has been a series of ongoing government policies to mitigate the economic effect of the pandemic, we do not know to what extent these policies have been effective. Using two-period panel data (before and during the pandemic) on 419 Italian firms, this study examines the impact of government policies on firms using first difference estimation. The results show that firms that received a government grant in relation to the COVID-19 pandemic saw on average an $11 \%$ increase in sales revenue by the end of June 2020 compared to those yet to receive grants. A sectoral decomposition of the analysis indicates government policy to be effective in the services sector if performance is measured by sales revenue.
\end{abstract}

Keywords Firm performance $\cdot$ COVID-19 pandemic $\cdot$ Sales revenue $\cdot$ Italy

\footnotetext{
Danny Turkson

d_turkso@uncg.edu

Nana Boakyewaa Addai

nbaddai@uncg.edu

Farhat Chowdhury

f_chowdh@uncg.edu

Fatima Mohammed

f_mohammed@uncg.edu
}

1 Economics Department, University of North Carolina at Chapel Hill, 141 South Road, Gardner Hall 107, CB\# 3305, Chapel Hill, NC 27599, USA

2 Economics Department, Bryan School of Business and Economics, University of North Carolina at Greensboro, Greensboro, NC, USA

3 Department of Information Systems and Supply Chain Management, Bryan School of Business and Economics, University of North Carolina at Greensboro, Greensboro, NC, USA 


\section{Introduction}

The effect of COVID-19 has been far reaching as it has gone beyond just the disease and finding ways to curb it to impacting all aspects of life; social, business, and economical. All over the world, governments have been faced with the pressure to minimize the effect of the pandemic on its citizens. While approaches vary across governments, most programs and policies implemented in the attempt to minimize the spread and effect of this pandemic widely include some form of restriction on social mobility, shut down of social and business ventures, and government aid to people to help sustain welfare.

The effect of this pandemic has been severely detrimental to most businesses starting from borders being closed (hence impacting international trade), businesses shutting down (either temporarily or permanently), and consumers cutting down on spending. Consequently, most firms have gone out of business or reduced operations, resulting in the layoff of several workers. To prevent the collapse of most businesses and the potential rippling consequences on the economy, most governments have resolved to give some form of assistance to businesses to sustain their operations. For example, the United States passed the Coronavirus Aid, Relief, and Economic Security (CARES) Act in March including the Paycheck Protection Program, a program aimed at providing small businesses with the resources they need to maintain their payroll, hire back employees who may have been laid off, and cover applicable overhead costs (US Department of the Treasury 2020).

As part of measures to mitigate the economic effects of the COVID-19 pandemic, EU member states committed to providing liquidity support to vulnerable companies consisting of public guarantee schemes and deferred tax payments, estimated at about $16 \%$ of EU GDP (European Council 2020). In South Africa, there was the Debt Relief Fund of over R500 million to provide relief for existing debts and repayments and to assist SMMEs in acquiring raw materials and paying for labor and other operational costs (Dlothi and du Plessis 2020). Generally, the magnitude of government intervention was largely dependent on the spread and severity of the disease in an area or country; the more widespread the disease, the more restrictions a government might have to place on its citizens. These restrictions were (and are still) likely to expose businesses to extreme economic conditions that have the ability to threaten their very existence.

One country that was terribly affected by the virus in the early days of the pandemic was Italy. Italy was reported to have had the highest number of coronavirus cases in Europe, as well as outside China on March 23th (Duddu 2020). As of March 27th, the country had reported the highest number of deaths from COVID19 in the world. In response to the growing pandemic in the country, the Italian government on March 9th imposed a national quarantine to restrict the movement of the population except for necessity, work, and health circumstances. Moving forward, all public services such as transport, and all businesses except for strategic operations such as supermarkets and pharmacies, were ordered to be closed on 22nd March until 3rd April to prevent the spread of the virus. 
Italy accounted for nearly $2.4 \%$ (\$2.1 trillion) of the world's GDP in 2018 (Orion Market Research Private Limited 2020). The country's economy is classified into automobile, food and beverage, aviation, BFSI, ${ }^{1}$ retail, travel and tourism, healthcare, and others. Preliminary estimates predicted that Italy could lose $\$ 8.3$ bn in tourism revenue due to the coronavirus pandemic (Duddu 2020). Firms that provide accommodation, food, and entertainment (such as hotels and restaurants) had already experienced tremendous business losses.

To sustain the businesses and prevent them from bankruptcy during the pandemic, the Italian government implemented the 'Liquidity Decree' on April 9th, 2020. The decree was set to provide loan guarantees, government assumption of non-market risks, and certain targeted tax relief. According to KPMG's cooperative report updated on 24th June 2020, the Italian government committed to allocating $€ 25$ million to support tourism and the logistics and transportation industry, which have been most severely affected by the pandemic (KPMG 2020). With government support, there was an agreement between the Italian Banking Association and various professional associations to set up a large-scale moratorium on debt repayment, including mortgages and repayments of small loans and revolving lines of credit. The funding limit for the banking system has been raised from $€ 1$ million to $€ 3$ million by the National Institute for Promotion and the Development Finance institution to provide subsidized loans to SMEs and mid-caps to induce cash flow and investment (KPMG 2020). The Central Fund issued guarantees free of charge until December 31, 2020 for companies with less than 499 employees and loans amounting up to $€ 5$ million. Additionally, struggling firms whose loan amount was less than $25 \%$ of their total turnover and those who had a total turnover of less than $€ 3.2$ million were guaranteed $100 \%$ of loans applied.

Following EU legislation, a coinsurance system was applied where the state would bear $90 \%$ of the non-market risks of the company for SACE-backed loans (Italy's export credit agency board). Moreover, SACE announced to help SMEs with a package of $€ 4$ million to help improve their cash flow and diversify the export market. A 'Relaunch Fund' was introduced to support joint-stock companies from which they could draw money for investment or buy shares listed on the secondary market. To encourage innovative start-ups in these difficult times, additional resources of $€ 100$ million (for 2020) were allocated by the Relaunch Decree. Other measures by the government included the payment of excise duties on natural gas and the ease and suspension of electricity and taxes on sugar and plastic for Italian companies. Although there has been a series of ongoing government policies, the true impact of these policies on firm performance has not been examined and this is what our study seeks to achieve. Our study aims at estimating the impact of government policy on firm performance among Italian firms during the COVID-19 pandemic. We further examine the effect of government support on firm performance in the manufacturing and service sectors.

\footnotetext{
${ }^{1}$ Banking, Financial, Service and Insurance.
} 


\section{Conceptual framework}

Many studies have used different indicators as a measure for firm performance, some of which are firm location, returns on assets, innovation, sales growth, and productivity. The most common are sales growth and returns on assets. Artz et al. (2010), studying the impact of research and development, product innovation, and patents on firm performance, used sales growth to measure firms' performance. Based on a longitudinal study using three stage least squares, they found a positive relationship between product announcement and firm performance. Also, studies by Asimakopoulos et al. (2009) and Lazăr (2016) used company sales growth as a measure of firms' performance. Diverting from the norm, Crespo and Clark's (2012) study on manufacturing firms in Europe employed variables like net working capital, sales, and asset mix as a measure of profitability and performance. Hansen and Wernerfelt (1989) studied the determinants of firm performance among economic and organizational variables using the least square estimation on three different models. Their findings were that the two effects are slightly independent, with organizational variables affecting firm performance twice as much as economic variables. Using data from 293 U.S. firms, Huselid et al. (1997) measured the determinants of firm performance and found effectiveness of human resource management, cash flow, productivity, and market value as the significant determinants of firm performance.

According to Hansen and Wernerfelt (1989), a firm's performance can be determined by internal and external factors. Internal factors are made up of characteristics of firms which reflect the firms' response to any changes in the market. These factors may include the finances, goods produced, services offered, suppliers, staff, marketing strategy, and communication. The external factors are the factors which are outside of the control of the firm and include legal, social, environmental, political, and economic factors (see Fig. 1). The recent pandemic serves as a typical example of an external factor that has impacted businesses and their operations. For example, Krieger et al. (2021) found that out of 1400 dividend-paying firms in the United States, 213 cut dividends and 93 omitted dividends entirely in the second quarter of 2020 (when most of the country was on lockdown due to the pandemic). Our study gives credence to the assertion that firm performance (sales revenue) is influenced by internal and external factors: firm performance $=f$ (internal factors, external factors).

On the topic of how government aid affected firms' output during the pandemic, Green and Loualiche (2021) measured the level of local employment in response to the federal stimulus received by each state in the US during the pandemic. Their results emphasized the importance of fiscal measures as they found that the number of layoffs in public employment decreased for the states that had more funding. About 401,000 layoffs could be prevented in April and 1 million jobs salvaged through August due to the contribution of state funding. While this paper focused on public employment only, our paper studies the outcome variable for both public and private firms. In another study, Coccia (2021) found that countries that have higher investment in the health sector could reduce 


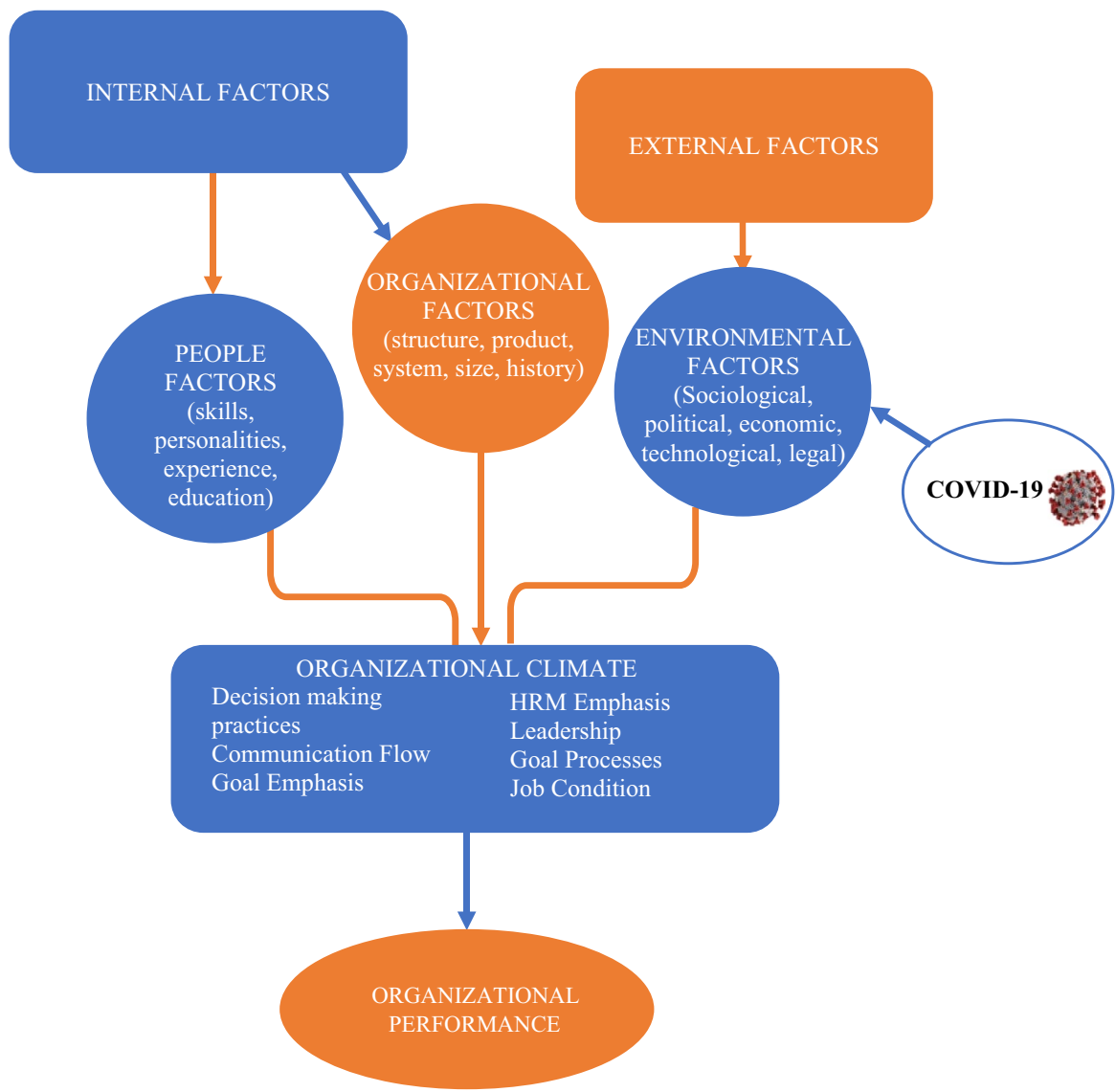

Fig. 1 Model of firm performance

fatality rate due to COVID-19 and shorten their lockdown period and concluded that government policies in favor of the health sector could (indirectly) mitigate the negative effects of the pandemic on firms. In yet another study, Didier et al. (2021) urged for government intervention intended to keep firms stable during the pandemic to be divided into two groups: one that adapts institutional framework to COVID shock and another that provides credit to firms. The authors recommended that in implementing policies such as loan forbearance, care be taken that firms are not encouraged to (deliberately) default in loan payments. In support of subsidized loans to small businesses, Horvath and Lang (2021) found that subsidized loans were not only effective at promoting investment and increasing employment, but also enhanced the productivity of firms over time. Other studies in the literature on how the pandemic affected firms looked at firm-specific characteristics such as business models (Mattera et al. 2021), financial and entrepreneurial risks (Kyung and Whitney, 2020), operating flexibility (Liu et al. 2021), and financial flexibility (Teng et al. 2021). 
Our paper is similar to the papers in the literature on government intervention to support businesses during the pandemic in the light that it studies how firm output changed with government support. However, none of the studies in the literature, as far as we know, has done a sector-based and multi-regional analysis in a country such as Italy, where the virus hit very hard in the early days of the pandemic and where the earliest (and longest) lockdown policies were enacted.

\section{Data and methods}

\section{Data and scope}

This study used the World Bank's Enterprise Survey (ES) data for Italy for 2019 and data from the COVID-19 Enterprise Survey follow-up in 2020 (Enterprise Surveys 2020). The 2020 data were collected from May 27th to June 30th, a period of relative calm, with focus on following up on the 760 firms which took part in the 2019 ES. Only 419 firms out of the 760 responded to the 2020 COVID-19 ES. The survey questions were in reference to April-May 2020 when lockdown restrictions were at their peak. To prevent a bias in the measurement, 2019 April and May were used as a base period for the 2020 data, since sales and firms' performance are seasonal and cyclical throughout the year. The firms sampled were non-agricultural firms which comprise of firms operating in the manufacturing and services sector. The survey used a stratified sampling technique. Enterprises were stratified based on industry, size, and region. The industrial stratification was designed as follows: four manufacturing industries (fabricated metal product, food and beverages, machinery and equipment, and other manufacturing) and two service industries (retail and other services). For the size stratification, the standard World Bank Enterprise Survey for classification of firms was used, that is, small (5-19 employees), medium (20-99 employees), and large (100 or more employees). For regional stratification, enterprises were classified based on their location in the five main regional zones: Northwest (Piedmont, Aosta Valley, Lombardy, Liguria), Northeast (Vento, EmiliaRomagna, Friuli-Venezia Guilia, Trentino-South Tyrol), Center (Marche, Tuscany, Lazio, Umbria), South (Campania, Apulia, Molise, Calabria, Abruzzo, Basilicata), and Islands (Sicily, Sardinia). A total of 760 firms were drawn from the stratified sample based on random sampling technique and these were 162 firms in the Northwest, 150 firms each in the Northeast, Center and Islands, and 148 firms in the South region.

To better understand our analysis, there is a need to know the impact of the COVID-19 pandemic in the various regions of Italy. Figure 2 shows the various Italian provinces and the COVID-19 cases per capita. This is the number of cases per the population of that particular province. The red areas are the most critical regions with at least 1 case out of every 100 people in that region. The northern regions are the most critical regions, and the southern and Islands are the least critical. 

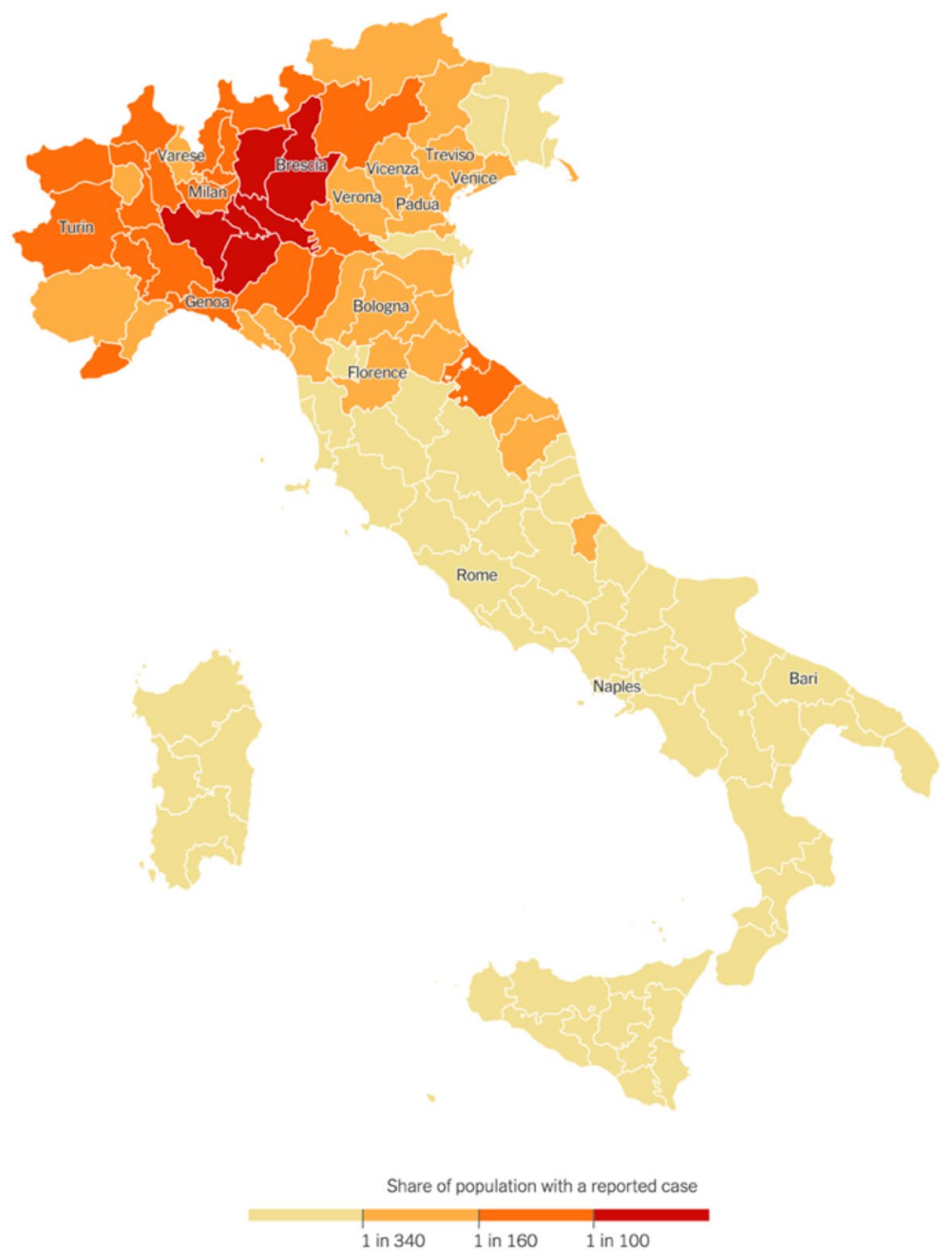

Fig. 2 Map of Italy showing COVID-19 case by province per capita as at July 2020 [Source: Italian Department of Civil Protection (Almukhtar et al. 2020)]

\section{Measure of variables}

Sales: This variable measures the change in sales comparing the two periods. This difference was recorded as a percent of the sales of the reference period. Respondents were asked to indicate by what percentage their sales had changed with respect to the reference period.

Demand: This variable measures the change in the level of demand for the product or service. Respondents were asked if the demand for their firms' goods or services had reduced, increased, or remained the same. 
Remote workers: Respondents were asked to indicate the percentage of their firms' employees who are currently working remotely. The assumption is that, in the reference period, there were no remote workers for most of the firms.

Payment of suppliers: This variable measures the change in the normal financial relationship between the firm and its suppliers. The respondents were asked to indicate if they had delayed payments to their firms' suppliers due to the pandemic.

Tax payment: This seeks to measure any changes in the fiscal relationship between the firm and the government. The respondents were asked to indicate if they had delayed payment of taxes on behalf of their firms due to the pandemic.

Loan repayment: Respondents were asked to indicate if they had any loan overdue due to the pandemic. This variable measures the creditworthiness of firms with regards to the financial sector.

Government policy: This variable measures the effectiveness of the government policies to salvage the dying firms due to the current pandemic. Respondents were asked if their firms had received any form of aid or grant from the government between May and April 2020 (current period). The variable indicates firms that received aid, those that expected to receive as at the time the respondents were interviewed, and those that did not expect to receive any form of government aid.

Working hours: With regards to the current number of staff, respondents were asked if their firms' hours per worker had increased, decreased or remained the same. The variable seeks to measure the productivity level of each worker in relation to production and sales.

Future expectation: Respondents were asked to indicate how many months they expected it would take for their sales to return to normal. This is a measure of the likelihood that a firm may stay in operation in the near future. This affects the amount of production and sales.

Level of COVID exposure: This variable measures the level of COVID exposure the firm faces based on their location. Regions with cases per capita greater than 1 in 160 are considered high risk, those with cases per capita between 1 in 160 and 1 in 340 are considered medium risk, and those with cases per capita less than 1 in 340 are considered low risk.

\section{Model specification}

The dependent variable of the study is sales revenue as a measure of firm performance. Since sales is a continuous variable, the best estimation technique to use is ordinary least squares (Gujarati 2005). The key thing to consider is that we are looking at two different periods, that is, before the pandemic ( $t=1$; Reference Period) and during the pandemic ( $t=2$; Current Period). The reference period is from April to May 2019 before the pandemic, and the current period is April-May 2020. This means that we are analyzing cross sectional data in two different periods; hence, we use a two-period panel data. According to Wooldridge (2016), the latent model will be 
Table 1 Descriptive statistics of dependent variables

\begin{tabular}{|c|c|c|c|c|c|c|c|}
\hline Variables & Frequency & Mean (\%) & $\begin{array}{l}\text { Standard } \\
\text { Dev. }\end{array}$ & $\begin{array}{l}\text { Skewness } \\
\text { test }\end{array}$ & Kurtosis test & $\operatorname{Min}(\%)$ & $\operatorname{Max}(\%)$ \\
\hline \multicolumn{8}{|l|}{ Sales revenue } \\
\hline Full sample & 419 & -37.05 & 36.48 & 0.772 & 0.250 & -100 & 100 \\
\hline $\begin{array}{l}\text { Manufactur- } \\
\text { ing sector }\end{array}$ & 264 & -35.60 & 33.42 & 0.373 & 0.488 & -100 & 100 \\
\hline $\begin{array}{c}\text { Services } \\
\text { sector }\end{array}$ & 155 & -39.50 & 41.18 & 0.537 & 0.020 & -100 & 80 \\
\hline
\end{tabular}

$y_{\text {it }}=\beta_{0}+\delta_{0} d 2_{t}+\beta_{k} x_{\text {it }}+v_{\text {it }}$ where $t=1,2$ and $d 2_{t}$ a dummy variable $d 2_{t}=\left\{\begin{array}{l}0 \text { if } t=1 \\ 1 \text { if } t=2\end{array}\right.$.

Hence, the model for the two-time periods is

$$
\begin{gathered}
\text { sales }_{i 1}=\beta_{0}+\beta_{k_{1}} x_{i 1}+a_{i}+u_{i 1} \text { when } t=1, \\
\text { sales }_{i 2}=\left(\beta_{0}+\delta_{0}\right)+\beta_{k_{2}} x_{i 2}+a_{i}+u_{i 2} \text { when } t=2,
\end{gathered}
$$

where: $\beta_{k}=$ vector of parameters; $x_{\mathrm{it}}=$ vector of time variant variables (variables that changed in the short run due to COVID-19); $a_{i}=$ fixed effects, that is a vector of time invariant variable (product, marketing strategy, law and regulations, competition, location, sector, years of existence, social factors, and political factors); $u_{\mathrm{it}}=$ idiosyncratic error term.

The estimation technique for two-period panel data is by estimating the first difference using the OLS estimation (Wooldridge 2016). Subtracting Eq. (1) from (2), we get the first-differenced equation

$$
\left(\text { sales }_{i 2}-\text { sales }_{i 1}\right)=\delta_{0}+\beta_{k_{2}} x_{i 2}-\beta_{k_{1}} x_{i 1}+\left(u_{i 2}-u_{i 1}\right) .
$$

The fixed effects (time invariant variables) drop out, since they are constant across all the time period

$$
\begin{gathered}
\Delta \text { sales }_{i}=\delta_{0}+\beta_{k_{2}} \Delta x_{i}+\left(\beta_{k_{2}}-\beta_{k_{1}}\right) x_{i 1}+\Delta u_{i}, \\
\Delta \text { sales }_{i}=\delta_{0}+\beta_{k_{2}} \Delta x_{i}+\Delta \beta_{k} x_{i 1}+\Delta u_{i},
\end{gathered}
$$

where $\delta_{0}$ captures the impact of COVID-19 on sales, and $x_{i}$ are the independent varables: demand, remote workers, payment to supplier, payment of taxes, loan repayment, government policy, hours per worker, and future expectation. 


\section{Results}

The change in the sales revenue varied depending on the sector. In both the manufacturing and services sectors, over $75 \%$ of the firms recorded a decline in sales revenue. Table 1 also shows the average changes in sales revenue in the two sectors. Overall, the full sample saw an average of $37 \%$ decline in sales revenue, with lower sales in the manufacturing sector averaging 35\% and the services sector being $4 \%$ worse off. In addition, skewness and kurtosis tests were conducted and found $P$ values above 0.05 for the full sample and manufacturing, and services sectors revealed a $P$ value above 0.01 for kurtosis. This reveals that sales revenue is normally distributed across the whole sample.

Unemployment has been a major concern in the COVID-19 pandemic. Most workers have been out of jobs, because the majority of firms cannot sustain the payment of recurring wages to their employees as a result of drastically reduced sales revenue. Figure 3 panel (a) shows the total number of workers the 419 firms lost during the pandemic (between April and May) in the various regions across the two sectors. Unemployed workers in this study include all employees who had not been actively working in that period, precisely workers who had: taken leave for more than 5 days or quit due to illness, childcare interruption, or mobility restrictions linked to the COVID-19 outbreak; been laid off; been furloughed due to the COVID-19 outbreak. The Central region lost the most workers in the manufacturing sector and the least in the service sector. Conversely, the Islands recorded the least workers lost in the manufacturing sector and the most in the service sector. However, to know the true changes in labor in the regions across sectors, we look at panel (b) which is the percent of workers lost in each region. This reveals that the North West region lost the highest proportion of workers across both sectors recording over $22 \%$ and $25 \%$ in manufacturing and services sectors, respectively. The South region lost the least proportion of workers (percentages).

From the survey, over $51 \%$ of the firms did not get access to any form of government grants. This could have been, because they did not qualify for the grants, or because they had no need for it and hence did not apply for it. Figure 4 shows the types of COVID-19 government grants which were available to firms. About $28 \%$ of the firms had access to deferral of payment grants, which comprises deferral of credit payments, rent or mortgage, suspension of interest payments, or rollover of debt. There was some form of new credit made available by the government to $22 \%$ of the firms which had access to government grants. Wage subsidies were the most used type of grant by the firms (33\% of firms benefit from it), since wages make up the largest proportion of recurring costs for most firms. Only $18 \%$ of the firms benefited from fiscal exemption or some form of tax reduction. It is important to note that some of the firms benefited from more than one of the government policies. Among the firms that receive some form of government grants, $39 \%$ of the firms profited from just one grant, $28 \%$ had two grants, and $21 \%$ received three grants. Only $9 \%$ and $3 \%$ benefited from four and five or more grants, respectively.

Regarding firm size, the government grants favored the large firms and the small firms more than the medium firms. Figure 5 shows the firm size and grant status. 

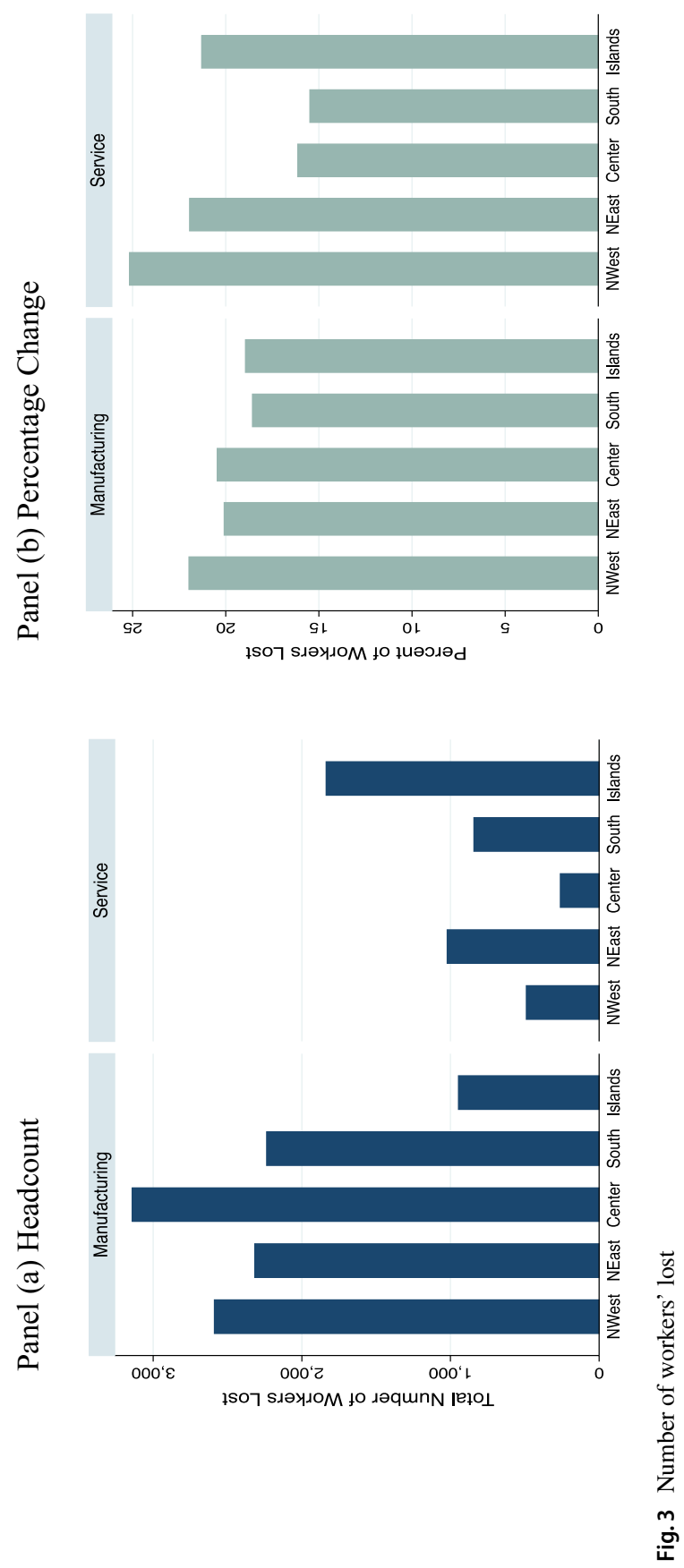

SN Business \& Economics 


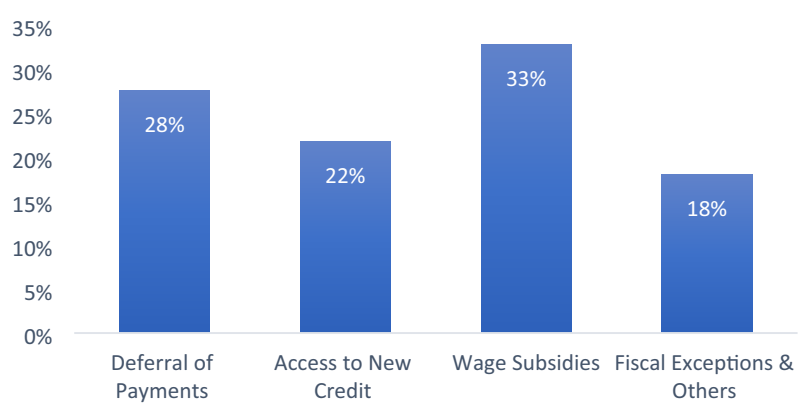

Fig. 4 Type of grants and the percentage of firms

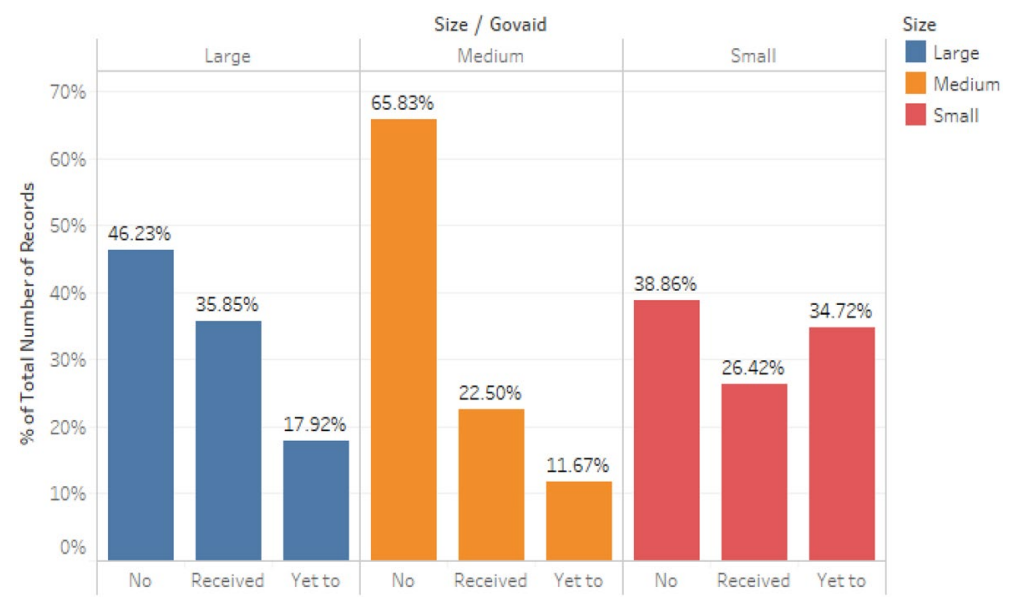

Fig. 5 Government grants across firm size

Only about $39 \%$ of the small firms were not expecting any grant at the time of the survey; the rest $(61 \%)$ of them had either received a grant $(26 \%)$ or were expecting to receive one in the next 3 months (35\%). Majority of the large firms had received (36\%) grants and $18 \%$ were still yet to receive any. Overall, about $46 \%$ of the large firms did not have access to government grants. Medium firms were the worst off when it came to government grants. Only about $34 \%$ had access to some form of government grant ( $22 \%$ had received it and $12 \%$ were yet to receive it).

Furthermore, considering the accessibility of government grants in each region, the central region benefited the most having about $62 \%$ of its firms receiving or expecting to receive some form of grant (see Fig. 6).

Being forward-looking is an integral part of firm performance and existence. In times of crisis, what makes some firms keep at it and not shut down is usually the hope of things getting better in the long run. Respondents were asked to predict how many months from the time of the survey it would take for their sales revenue to return to normal. Figure 7 shows the distribution of predictions of the number of 


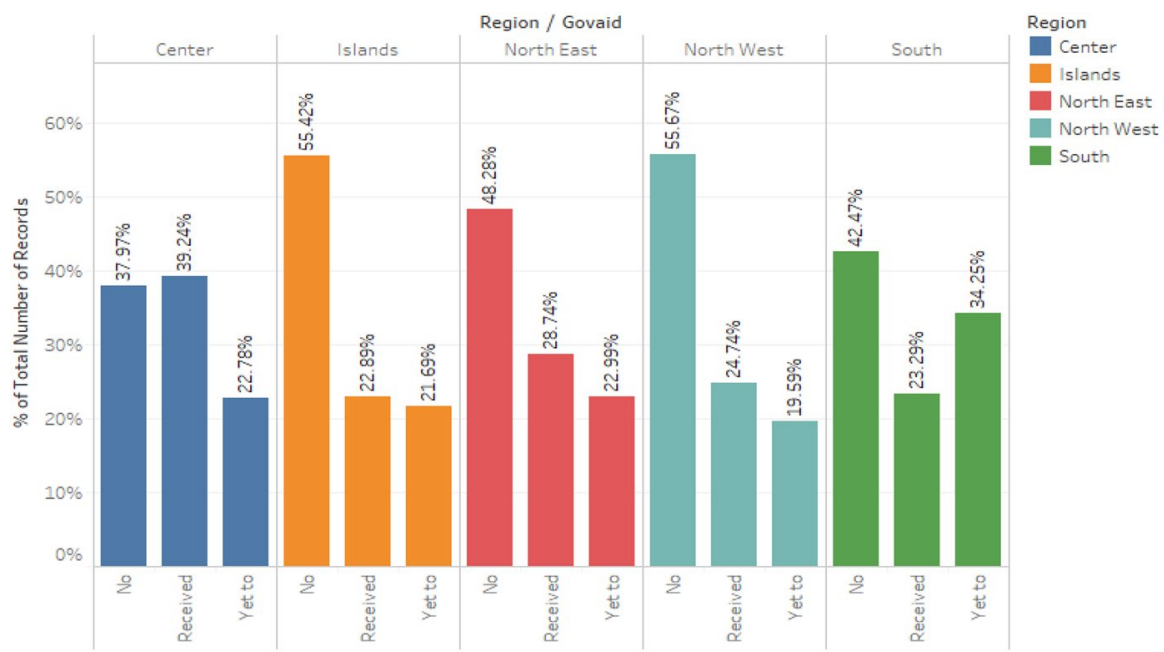

Fig. 6 Government grants across firm size

Panel (a) Region

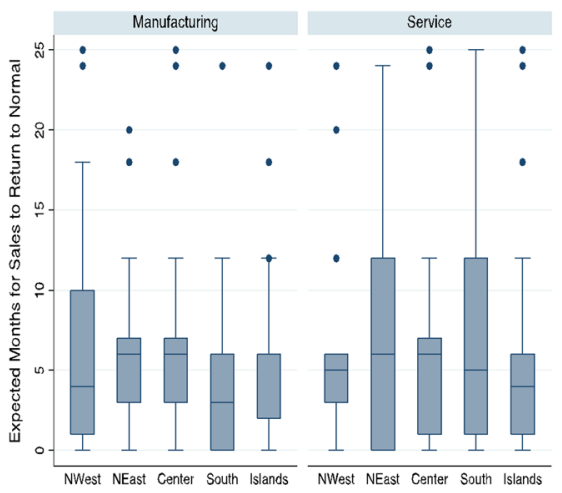

Panel(b) Firm Size

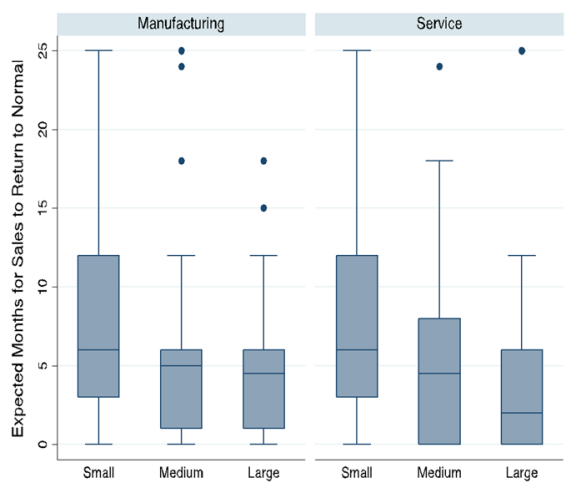

Fig. 7 Distribution of expected months for sales to normalize

months it was expected to take for firms' sales revenue to normalize. From panel (a), manufacturing firms in the South expected sales to return to normal much faster than their counterparts in other regions. Likewise in the services sector, the Islands expected sales to normalize much sooner. In panel (b), small firms had a worse expectation for the future than larger firms.

In addition, Table 2 gives a brief description of the independent variables which are categorized into dummy and continuous variables. Over $66 \%$ of the firms recorded a decline in demand for their products or services. The three dummy variables 'delay payment to suppliers', 'delay payment to taxes', and 'overdue loan payment' serve as debt indicators of the firms. Interestingly, the majority of firms said 'no' to questions like 'delay payment to suppliers' (62.5\%), 
Table 2 Descriptive statistics of independent variables

\begin{tabular}{|c|c|c|c|c|}
\hline \multirow[t]{2}{*}{ Dummy variables } & \multicolumn{2}{|l|}{ Full sample } & \multicolumn{2}{|c|}{ Firms with decline in sales } \\
\hline & Frequency & Percentage & Frequency & Percentage \\
\hline \multicolumn{5}{|l|}{ Demand } \\
\hline Increase & 26 & 6.25 & 2 & 0.65 \\
\hline No change & 112 & 26.92 & 38 & 12.38 \\
\hline Decrease & 278 & 66.83 & 267 & 86.97 \\
\hline \multicolumn{5}{|c|}{ Delay payment to suppliers } \\
\hline No & 255 & 62.50 & 166 & 55.15 \\
\hline Yes & 153 & 37.50 & 135 & 44.85 \\
\hline \multicolumn{5}{|l|}{ Delay payment to taxes } \\
\hline No & 346 & 85.22 & 244 & 81.61 \\
\hline Yes & 60 & 14.78 & 55 & 18.39 \\
\hline \multicolumn{5}{|l|}{ Overdue loan payment } \\
\hline No & 381 & 90.93 & 274 & 88.96 \\
\hline Yes & 38 & 9.07 & 34 & 11.04 \\
\hline \multicolumn{5}{|l|}{ Government grant } \\
\hline Yes, received & 116 & 27.68 & 80 & 25.97 \\
\hline Expected in 3 months & 100 & 23.87 & 89 & 28.90 \\
\hline No & 203 & 48.45 & 139 & 45.13 \\
\hline \multicolumn{5}{|l|}{ Hours per worker } \\
\hline Increase & 8 & 1.92 & 0 & 0.00 \\
\hline No change & 135 & 32.37 & 59 & 19.28 \\
\hline Decrease & 274 & 65.71 & 247 & 80.72 \\
\hline \multicolumn{5}{|l|}{ Level of COVID exposure } \\
\hline Low & 156 & 37.23 & 112 & 36.36 \\
\hline Medium & 79 & 18.85 & 60 & 19.48 \\
\hline High & 184 & 43.91 & 136 & 44.16 \\
\hline Continuous variables & Mean & Standard Dev. & Mean & Standard Dev. \\
\hline Remote workers & 8.35 & 17.17 & 7.54 & 16.58 \\
\hline Future expectation & 6.03 & 5.94 & 7.27 & 6.01 \\
\hline
\end{tabular}

'delay payment to taxes' (85.22\%), and 'overdue loan payment' (90.93\%). This shows that COVID-19 did not affect the debt performance of the firms much. Majority of the firms had a decrease in the number of working hours per worker $(65.71 \%)$ as social interaction was limited according to government rule. This led to paycheck cuts and partial unemployment. About $44 \%$ of the firms were located in areas with high levels of COVID exposure.

The third and fourth columns of Table 2 show descriptive statistics for firms with a decline in sales revenue. Similar to the full sample, a large number of firms whose sales revenue declined $(86.97 \%)$ recorded a decrease in demand and only an insignificant number $(0.65 \%)$ had an increase in demand due to COVID-19. 
Table 3 Descriptive statistics of independent variables based on sectors

\begin{tabular}{|c|c|c|c|c|}
\hline \multirow[t]{2}{*}{ Dummy variables } & \multicolumn{2}{|c|}{ Manufacturing } & \multicolumn{2}{|l|}{ Service } \\
\hline & Frequency & Percentage & Frequency & Percentage \\
\hline \multicolumn{5}{|l|}{ Demand } \\
\hline Increase & 12 & 4.58 & 14 & 9.09 \\
\hline No change & 76 & 29.01 & 36 & 23.38 \\
\hline Decrease & 174 & 66.41 & 104 & 67.53 \\
\hline \multicolumn{5}{|c|}{ Delay payment to suppliers } \\
\hline No & 166 & 64.59 & 89 & 58.94 \\
\hline Yes & 91 & 35.41 & 62 & 41.06 \\
\hline \multicolumn{5}{|l|}{ Delay payment to taxes } \\
\hline No & 224 & 86.82 & 122 & 82.43 \\
\hline Yes & 34 & 13.18 & 26 & 17.57 \\
\hline \multicolumn{5}{|l|}{ Overdue loan payment } \\
\hline No & 247 & 93.56 & 134 & 86.45 \\
\hline Yes & 17 & 6.44 & 21 & 13.55 \\
\hline \multicolumn{5}{|l|}{ Government grant } \\
\hline Yes, received & 70 & 26.52 & 46 & 29.68 \\
\hline Expected in 3 months & 66 & 25.00 & 34 & 21.94 \\
\hline No & 128 & 48.48 & 75 & 48.39 \\
\hline \multicolumn{5}{|l|}{ Hours per worker } \\
\hline Increase & 7 & 2.67 & 1 & 0.65 \\
\hline No change & 82 & 31.30 & 53 & 34.19 \\
\hline Decrease & 173 & 66.03 & 101 & 65.16 \\
\hline \multicolumn{5}{|l|}{ Level of COVID exposure } \\
\hline Low & 99 & 37.50 & 57 & 36.77 \\
\hline Medium & 54 & 20.45 & 25 & 16.13 \\
\hline High & 111 & 42.05 & 73 & 47.10 \\
\hline Continuous variables & Mean & Standard Dev. & Mean & Standard Dev. \\
\hline Remote workers & 8.94 & 15.94 & 7.33 & 19.13 \\
\hline Future expectation & 5.98 & 5.87 & 6.11 & 6.06 \\
\hline
\end{tabular}

The other independent variables of firms with decline in sales revenue also had very similar figures to the full sample; this means that these firms are the main drivers of the full sample. None of such firms had an increase in the number of working hours per worker, suggesting that restrictions due to the COVID pandemic had a profound effect on their working hours.

Table 3 has divided firms into manufacturing and services industries. The figures of the independent variables show that there was a greater impact of the disease on the services industries compared to the manufacturing industries. This is to be expected as the delivery of services often requires personal contact 
Table 4 Empirical results for the full sample

\begin{tabular}{|c|c|c|}
\hline \multicolumn{3}{|l|}{ Dependent variable: sales revenue } \\
\hline Variables & Coefficient & $P$ value \\
\hline \multicolumn{3}{|l|}{ Demand } \\
\hline Increase & $23.075 * * *$ & 0.001 \\
\hline Decrease $[$ base $=$ no change $]$ & $-20.545 * * *$ & 0.001 \\
\hline Remote workers & $0.223 * * *$ & 0.003 \\
\hline Delay payment to suppliers & -4.046 & 0.194 \\
\hline Delay payment of taxes & -6.208 & 0.172 \\
\hline Overdue loan payment & $-12.332 * *$ & 0.019 \\
\hline \multicolumn{3}{|l|}{ Government grant } \\
\hline Received & 1.243 & 0.714 \\
\hline Expected in 3 months [base $=$ no grant $]$ & $-9.799 * * *$ & 0.009 \\
\hline \multicolumn{3}{|l|}{ Hours per worker } \\
\hline Increase & 11.252 & 0.263 \\
\hline Decrease $[$ base $=$ no change $]$ & $-11.786^{* * * *}$ & 0.006 \\
\hline Future expectation & $-1.106^{* * * *}$ & 0.001 \\
\hline \multicolumn{3}{|l|}{ Level of COVID exposure } \\
\hline Medium & 1.787 & 0.659 \\
\hline High $[$ base $=$ low $]$ & -0.555 & 0.851 \\
\hline _cons & $-6.887 * *$ & 0.021 \\
\hline Number of observations & 391 & \\
\hline Adjusted $R$-squared & 0.495 & \\
\hline Prob $>F$ & 0.001 & \\
\hline
\end{tabular}

Note: $* * *, * *$, and $*$ significant at $1 \%, 5 \%$, and $10 \%$, respectively

and firms involved in this kind of business had to either close down or decrease their business hours.

\section{Estimation results}

The OLS estimation for the factors that influence firm performance (change in sales revenue) during the COVID-19 pandemic is presented in Table 4 . With the exception of delayed payment to suppliers, delayed payment of taxes, and level of exposure, all the other variables were statistically significant determinants of sales revenue. During the period of the pandemic, while most of the firms had to shut down or slow down production, some firms indicated an increase in demand. Our estimations show that firms which had a decrease in the demand of their goods or services performed worse compared to those with an increase. A firm with no change in demand for its product(s) or service(s) had $23.1 \%$ less sales compared to those with increased demand and $20.5 \%$ more sales than those with decreased demand. Working from home was a significant determinant of sales revenue. One percentage point increase in the number of remote workers averagely increases sales revenue by $0.2 \%$. 
Table 5 Empirical results from the interaction effect

\begin{tabular}{|c|c|c|}
\hline \multicolumn{3}{|l|}{ Dependent variable: sales revenue } \\
\hline Variables & Coefficient & $P$ value \\
\hline \multicolumn{3}{|l|}{ Demand } \\
\hline Increase & $23.248 * * *$ & 0.001 \\
\hline Decrease $[$ base $=$ no change $]$ & $-20.723 * * *$ & 0.001 \\
\hline Remote workers & $0.217 * * *$ & 0.004 \\
\hline Delay payment to suppliers & -4.110 & 0.193 \\
\hline Delay payment of taxes & -6.206 & 0.174 \\
\hline Overdue loan payment & $-12.415^{* *}$ & 0.021 \\
\hline \multicolumn{3}{|l|}{ Hours per worker } \\
\hline Increase & 11.477 & 0.252 \\
\hline Decrease $[$ base $=$ no change $]$ & $-11.843 * * *$ & 0.008 \\
\hline Future expectation & $-1.060 * * *$ & 0.001 \\
\hline \multicolumn{3}{|l|}{ Interaction variables } \\
\hline No grant $*$ medium risk & 4.687 & 0.438 \\
\hline No grant $*$ high risk & -1.372 & 0.710 \\
\hline Yet to receive $*$ low risk & -7.884 & 0.119 \\
\hline Yet to receive $*$ medium risk & $-13.768 *$ & 0.102 \\
\hline Yet to receive $*$ high risk & $-9.736^{*}$ & 0.094 \\
\hline Receive * low risk & -1.128 & 0.836 \\
\hline Receive $*$ medium risk & 4.045 & 0.435 \\
\hline $\begin{array}{l}\text { Receive } * \text { high risk }[\text { base }=\text { no grant } \\
* \text { low risk] }\end{array}$ & 1.848 & 0.729 \\
\hline _cons & $-6.955^{* *}$ & 0.023 \\
\hline Number of observations & 391 & \\
\hline Adjusted $R$-squared & 0.497 & \\
\hline Prob $>F$ & 0.001 & \\
\hline
\end{tabular}

Note: $* * *, * *$, and $*$ significant at $1 \%, 5 \%$, and $10 \%$, respectively

The repayment of loans indicates the financial standing of firms, and hence, an overdue loan repayment is significant to sales revenue as the results shows. Firms with loan repayment overdue during the pandemic had a $12 \%$ decline in sales revenue on average, compared to those without a loan overdue. Firms that had a decline in workforce, that is decrease in working hours, had an $11.8 \%$ decrease in sales revenue compared to those with no change in working hours. On the other hand, a few firms that had an increase in working hours were expected to have enjoyed a $11.3 \%$ increase in sales revenue compared to those firms whose working hours remained unchanged. Furthermore, our estimates indicate that a 1-month delay in a firm's expectation of when its sales will return to normal decreased its sales revenue by an average of $1.1 \%$.

Government policy during the pandemic has been crucial to the economy and its major stakeholders of which firms are not an exception. The results show that firms which did not receive or apply for any form of COVID-19 government grant had just $1.2 \%$ less in sales revenue compared to those who received it, and $9.8 \%$ increase 
Table 6 Empirical results for change in sales based on sector

\begin{tabular}{|c|c|c|c|c|}
\hline \multirow{2}{*}{$\begin{array}{l}\text { Sector: } \\
\text { Variables }\end{array}$} & \multicolumn{2}{|c|}{ Manufacturing } & \multicolumn{2}{|l|}{ Service } \\
\hline & Coefficient & $P$ value & Coefficient & $P$ value \\
\hline \multicolumn{5}{|l|}{ Demand } \\
\hline Increase & $21.185^{* *}$ & 0.017 & $21.128 * *$ & 0.014 \\
\hline Decrease $[$ base $=$ no change $]$ & $-20.847 * * *$ & 0.001 & $-18.400 * *$ & 0.043 \\
\hline Remote workers & $0.257 * *$ & 0.008 & $0.271 * * *$ & 0.009 \\
\hline Delay payment to suppliers & -4.302 & 0.296 & -3.965 & 0.383 \\
\hline Delay payment of taxes & -8.950 & 0.120 & -3.882 & 0.578 \\
\hline Overdue loan payment & $-18.471 * *$ & 0.011 & -5.760 & 0.451 \\
\hline \multicolumn{5}{|l|}{ Government grant } \\
\hline Received & 3.483 & 0.449 & -1.261 & 0.807 \\
\hline Expected in 3 months [base $=$ no grant $]$ & -6.917 & 0.136 & $-17.194 * * *$ & 0.004 \\
\hline \multicolumn{5}{|l|}{ Hours per worker } \\
\hline Increase & $18.389^{*}$ & 0.096 & 6.042 & 0.461 \\
\hline Decrease $[$ base $=$ no change $]$ & -6.095 & 0.257 & $-22.333 * * *$ & 0.004 \\
\hline Future expectation & -0.482 & 0.196 & $-2.073 * * *$ & 0.001 \\
\hline \multicolumn{5}{|l|}{ Level of COVID exposure } \\
\hline Medium & -1.495 & 0.765 & 0.603 & 0.933 \\
\hline High $[$ base $=$ low $]$ & -3.699 & 0.338 & 1.724 & 0.722 \\
\hline _cons & $-11.954 * * *$ & 0.001 & 3.105 & 0.552 \\
\hline Number of observations & 249 & & 142 & \\
\hline Adjusted $R$-squared & 0.431 & & 0.642 & \\
\hline Prob $>F$ & 0.000 & & 0.000 & \\
\hline
\end{tabular}

Note: $* * *, * *$, and $*$ significant at $1 \%, 5 \%$, and $10 \%$, respectively

compared to those yet to receive the grant (who were expecting the grant in the next 3 months). Government aid then seemed to have reached firms that showed real need for assistance, since those firms that did not get (and were not expecting) any grants were not much worse off at the time of the survey in terms of their sales revenue. The average impact of COVID-19 on sales revenue is the constant. This shows that, on average, the pandemic caused a $6.9 \%$ decline in sales revenue of firms with no government aid who were located in a low-risk zone.

Table 5 shows the interaction of government policy with firms' level of COVID19 exposure to explore the basis of selection for firms to receive grants. The estimates (obtained Table 4) show a possibility that the government might have selected firms to which grants were given based on other criteria apart from the firms' expression of need for assistance. We interacted the different categories of government grant with the levels of exposure, as presented in Table 5. The results show that firms located in medium- and high-level COVID risk zones who were yet to receive grants had a $13.8 \%$ and $9.7 \%$ decrease in sales, respectively, compared to 
firms in a low-risk region who did not receive grants. This shows that COVID exposure levels played an important role in the selection of firms to receive relief grants.

To know what the main drivers of sales revenue in the different sectors were, we did a decomposition analysis of the manufacturing and services sectors. The estimation for the determinants of sales revenue in the manufacturing and services sectors is presented on the left side (first and second columns) and right side (third and fourth columns) of Table 6, respectively. In the manufacturing sector, the factors which significantly influenced firm performance were demand, remote workers, overdue loan payment, and hours per worker. Only demand, remote workers, hours per worker, future expectation, and government policy had a significant effect on sales revenue of the service sector firms. With regards to demand, manufacturing firms with an 'increase' and 'decrease' in demand for their product during the pandemic had $21.2 \%$ more and $20.8 \%$ less sales revenue than their counterparts who had 'no change' in demand, respectively. In the service sector, there was a $21.1 \%$ increase and $18.4 \%$ reduction in sales revenue of firms with 'increase in demand' and those with a 'decrease in demand', compared to their counterpart service firms which had 'no change in demand'.

Furthermore, a $1 \%$ point increase in the number of remote workers increased sales revenue by approximately $0.3 \%$ in both sectors. Manufacturing firms that had an overdue loan repayment had an $18.5 \%$ decrease in sales compared to those that did not have any lagged loan repayment. Manufacturing firms with an increase in working hours had an $18.4 \%$ increase in sales revenue compared to those without a change in working hours. Likewise in the services, sector firms with a decrease in working hours had a $22.3 \%$ decline in sales revenue compared to those with no change in working hours. Future expectations significantly influenced only sales in the services sector. The estimations indicate that a 1-month delay in a firm's expectation of when its sales would return to normal decreased its sales revenue by $2 \%$.

Government policy had a significant impact in only the services sector. Services firms without a grant had a $1.3 \%$ and $17.2 \%$ increase in sales revenue compared to those who 'received the grant' and those who were 'expecting the grant', respectively.

\section{Discussion}

Our findings of the proportion of workers lost in the various regions are most likely because of the specialization of industries in the various regions: the Islands are dominated by the services firms (due to the numerous tourist sites in the Islands region), whereas manufacturing firms dominate the Central region. The difference in the proportion of workers lost between the South region and the Northern provinces could most probably be due to high levels of the COVID-19 cases per capita recorded in the northern provinces of Italy (see Fig. 2).

Although the COVID-19 cases per capita was worse in the Northern regions, firms in those locations seemed not to have immediate access to government grants. That the Central region benefited most from government grants is most likely explained by the fact that firms in that region were characterized by immense 
unemployment during the pandemic (the highest number of lost workers). A less probable explanation would be that since Rome, the heart of all policy decisions is situated in the central region of Italy (and since it is the capital city), firms in the region had more access to grants than firms in other parts of the country. In addition, wage subsidies were the most preferred type of government grant, while fiscal exemption or tax reduction was least preferred by firms. Tax reduction seems to have a long-run impact on the firm's operations contrast to wage subsidies which has immediate impact. Firms which had input/raw materials in stock prior to the pandemic may fancy the government subsiding their employees' wages rather than tax reduction.

With regard to future expectations, small firms had a bleaker outlook for recovery. This is most likely because these firms have limited ability to absorb the economic shock from the pandemic compared to larger firms which have better organizational structures in place to serve as "shock absorbers" in critical situations. From the estimation results, working remotely seems to be very efficient. This is probably due to the reduced operating cost of working from home, and the extension of the firms target market through sales representatives working remotely across the country. This strategy should be encouraged post-COVID-19 pandemic, because a full-time remote working or a hybrid of on-site and remote may save the firms some operating cost and expand their reach. Also, we found that government aid seemed to have reached firms that showed real need for assistance is an indication that the Italian government was efficient in the distribution of aid and its policies to keep firms active and reduce unemployment during the pandemic are commendable much focus must be given to the smaller firms.

\section{Conclusion}

In sum, the empirical findings indicated that with the exception of delayed payment to suppliers, delayed payment of taxes and level of exposure all the other variables significantly determined firms' sales growth. Firms with government grants in relation to the COVID-19 pandemic saw an $11 \%$ increase in sales revenue by the end of June 2020 compared to those yet to receive the grant, and just a $1 \%$ increase compared to those that did not receive any grant (including those that did not apply for grants). A sectoral decomposition of the analysis indicates that government policy affects both the services sector and the manufacturing sector. Due to the limiting nature of the data, we could not analyze the impact of the policies in the various industries in the manufacturing sector (fabricated metal product, food and beverages, machinery and equipment, and other manufacturing) and service sector (retail and other services).

In light of the findings from this study, government policy geared toward protecting businesses from shutting down during the pandemic should target improving sales growth in the services sector. Furthermore, cash grants and wage subsidies should be the main forms of government grants made available to firms, particularly medium-size firms, compared to fiscal reduction grants, because wage subsidies 
have a more immediate impact on firms in situations like one created by the pandemic. Although the northern part of Italy was the most severely affected region by COVID-19, the central region benefited the most from government aid, having about $62 \%$ of its firms receiving or expecting to receive some form of grant. The empirical results show the significant impact government policy could have if it were regionbased. A greater emphasis should be given by the government to provide provincebased grants to create a more even distribution of grants in the country.

Supplementary Information The online version contains supplementary material available at https://doi. org/10.1007/s43546-021-00170-6.

Acknowledgements Special thanks to Professor Martin Andersen of University of North Carolina at Greensboro, Economics Department, for critiquing and proofreading the manuscript. We thank you for your immense contribution.

Funding The authors declare that this work was not funded by any organization.

Data availability The authors declare that there is perfect data transparency and data will always be available at any time upon request.

Code availability The authors declare that Stata codes for running the estimations for this paper will be available upon request.

\section{Declarations}

Conflict of interest All authors declare that they have no known competing financial interests or personal relationships that could have appeared to influence the work reported in this paper.

Ethical approval This article does not contain any studies with human participants or animals performed by any of the authors.

\section{References}

Almukhtar S, Aufrichtig A, Bloch M, Calderone J, Collins K, Conlen M, Cook L, Gianordoli G et al (2020) Italy coronavirus map and case count. The New York Times. https://www.nytimes.com/inter active/2020/world/europe/italy-coronavirus-cases.html\#states. Accessed 15 Aug 2020

Artz KW, Norman PM, Hatfield DE, Cardinal LB (2010) A longitudinal study of the impact of R\&D, patents, and product innovation on firm performance. J Prod Innov Manag 27(5):725-740. https:// doi.org/10.1111/j.1540-5885.2010.00747.x

Asimakopoulos I, Samitas A, Papadogonas T (2009) Firm-specific and economy wide determinants of firm profitability: Greek evidence using panel data. Manag Financ 35(11):930-939. https://doi.org/ $10.1108 / 03074350910993818$

Coccia M (2021) The relation between length of lockdown, numbers of infected people and deaths of Covid-19, and economic growth of countries: lessons learned to cope with future pandemics similar to Covid-19. Sci Total Environ. https://doi.org/10.1016/j.scitotenv.2021.145801

Crespo G, Clark RA (2012) Analyzing the determinants of profitability, part 3: evidence from European manufacturers. Transf Pricing Rep 21(6):297-310

Didier T, Huneeus F, Larrain M, Schmukler SL (2021) Financing firms in hibernation during the COVID19 pandemic. J Financ Stab 53:100837. https://doi.org/10.1016/j.jfs.2020.100837

Dlothi K, du Plessis Q (2020) Relief packages and support to South Africans amid the COVID-19 pandemic. White and Case; Client Alert South Africa. https://www.whitecase.com/sites/default/files/ 
2020-04/relief-packages-support-south-africans-amid-the-covid-19-pandemic.pdf. Accessed 31 July 2020

Duddu P (2020) Coronavirus in Italy: outbreak, measures and impact. Published online at Pharmaceutical Technology. https://www.pharmaceutical-technology.com/features/covid-19-italy-coronavirusdeaths-measures-airports-tourism/. Accessed 31 July 2020

Enterprise Surveys (2020) The World Bank. http://www.enterprisesurveys.org. Accessed 25 May 2020

European Council (2020) Report on the comprehensive economic policy response to the COVID-19 pandemic. A Eurogroup Press Release. http://www.consilium.europa.eu/en/press/press-releases/ 2020/04/09/report-on-the-comprehensive-economic-policy-response-to-the-covid-19-pandemic/. Accessed 31 July 2020

Green D, Loualiche E (2021) State and local government employment in the COVID-19 crisis. J Public Econ 193:104321. https://doi.org/10.1016/j.jpubeco.2020.104321

Gujarati DN (2005) Basic econometrics, 4th edn. McGraw-Hill Book Company, New York

Hansen GS, Wernerfelt B (1989) Determinants of firm performance: the relative importance of economic and organizational factors. Strateg Manag J 10(5):399-411. https://doi.org/10.1002/smj.4250100502

Horvath A, Lang P (2021) Do loan subsidies boost the real activity of small firms? J Bank Financ 122:105988. https://doi.org/10.1016/j.jbankfin.2020.105988

Huselid MA, Jackson SE, Schuler RS (1997) Technical and strategic human resources management effectiveness as determinants of firm performance. Acad Manag J 40(1):171-188. https://doi.org/10. $2307 / 257025$

KPMG (2020) Italy Government and institution measures in response to COVID-19. Published online at KPMG International Cooperative. https://home.kpmg/xx/en/home/insights/2020/04/italy-gover nment-and-institution-measures-in-response-to-covid.html. Accessed 30 Aug 2020

Krieger K, Mauck N, Pruitt SW (2021) The impact of the COVID-19 pandemic on dividends. Financ Res Lett 42:101910. https://doi.org/10.1016/j.frl.2020.101910

Kyung A, Whitney S (2020) A study on the financial and entrepreneurial risks of small business owners amidst covid-19. In: 2020 IEEE international IOT, electronics and mechatronics conference (IEMTRONICS), pp 1-4

Lazăr S (2016) Determinants of firm performance: evidence from Romanian listed companies. Review of Economic and Business Studies 9(1):53-69. https://doi.org/10.1515/rebs-2016-0025

Liu H, Yi X, Yin L (2021) The impact of operating flexibility on firms' performance during the COVID19 outbreak: evidence from China. Financ Res Lett 38:101808. https://doi.org/10.1016/j.frl.2020. 101808

Mattera M, Gonzalez FS, Ruiz-Morales CA, Gava L (2021) Facing a global crisis-how sustainable business models helped firms overcome COVID. Corp Gov Int J Bus Soc. https://doi.org/10.1108/ CG-07-2020-0309

Orion Market Research Private Limited (2020) Impact of COVID-19 on the Italian Economy. Published online at Research and Markets. https://www.researchandmarkets.com/reports/5013540/impact-ofcovid-19-on-the-italian-economy. Accessed 30 Aug 2020

Teng X, Chang BG, Wu KS (2021) The role of financial flexibility on enterprise sustainable development during the COVID-19 crisis-a consideration of tangible assets. Sustainability 13(3):1245. https:// doi.org/10.3390/su13031245

US Department of the Treasury (2020) The CARES act works for all Americans. US Department of the Treasury. https://home.treasury.gov/policy-issues/care. Accessed 15 Aug 2020

Wooldridge JM (2016) Introductory econometrics: a modern approach, 6th edn. Nelson Education, Toronto 